\title{
Business to business digital content marketing: marketers' perceptions of best practice
}

\begin{abstract}
Purpose: B2B digital content marketing is an inbound marketing technique and hence offers a solution to the declining effectiveness of traditional interruptive marketing techniques. This study draws attention to this emerging phenomenon, offers a range of insights and reflections on good practice, and contributes to theoretical understanding of the role of digital content in marketing.
\end{abstract}

Design/methodology/approach: Semi-structured interviews were conducted with fifteen key informants involved in B2B content marketing in the USA, UK and France, in five industry sectors.

Findings: B2B digital content marketing is an inbound marketing technique, effected through web page, social media and value-add content, and is perceived to be a useful tool for achieving and sustaining trusted brand status. Creating content that is valuable to B2B audiences requires brands to take a 'publishing' approach, which involves developing an understanding of the audience's information needs, and their purchase consideration cycle. Valuable content is described as being useful, relevant, compelling and timely. Content marketing requires a cultural change from 'selling' to 'helping', which in turn requires different marketing objectives, tactics, metrics and skills to those associated with more traditional marketing approaches. The article concludes with a theoretical discussion on the role of digital content in marketing, thereby contextualising the findings from this study within a broader exploration of the role of digital content in marketing and relational exchanges

Originality: As the first research study to explore the use of digital content marketing in B2B contexts, this research positions digital content marketing with regard to prior theory, and provides both an agenda for further research, and suggestions for practice.

Keywords: B2B marketing; digital marketing; digital content marketing; content marketing; customer relationships; relationship marketing; inbound marketing.

Paper type: Research paper 


\section{Introduction}

According to Smith and Chaffey (2013) the web is a pull marketing environment in which companies pull customers to their brand websites through search engine optimisation and social media. In pull marketing, companies are seeking to capture the interest of customers who are already seeking information, advice, a product or a service. Recently, there has been growing interest in the potential of pull or inbound digital marketing in which customers and prospects actively seek out brands that provide engaging and valuable content which is relevant to their needs (Halligan and Shah, 2010). Not only does 'inbound marketing' positively discourage explicit selling messaging and a brand-centric approach, but it actively encourages brands to take a customer-centric perspective on their propositions and also engenders higher levels of trust from those customers and prospects that seek it out. This is consistent with the service dominant logic philosophy, in which customers are viewed as part of an extended enterprise and as co-producers of the firms' marketing. Further, Lusch and Vargo (2009, p.6) suggest that 'inbound marketing is made more effective and efficient and whole when your customers are viewed as a partner to be 'marketing with' or 'co-creators of value'. This stance heralds a paradigm shift from outbound (described by some as interruptive) to inbound marketing (Halligan and Shah, 2010).

Content is a key component of inbound marketing techniques, and hence an understanding of how content can be used in marketing, or more specifically, in engaging customers, is central to the development of an effective inbound marketing approach. There are some ambiguities as to the nature of content, and the definition of content marketing, which this research seeks to address. However, as a starting point we suggest that content includes the static content forming web pages, as well as dynamic rich media content, such as videos, podcasts, usergenerated content, and interactive product selectors (Smith and Chaffey, 2013), and adopt Pulizzi and Barrett (2008, p.8) widely used, but untested definition of digital content marketing: "the creation and distribution of educational and/or compelling content in multiple formats to attract and/or retain customers". This definition of digital content marketing was proposed to capture the use of digital content by a firm as a means of drawing B2B customers to their online space (e.g. a web-site or social media presence), and promoting ongoing interaction and engagement with the brand community. This is the notion of digital content marketing that is the focus of this article. Nevertheless, there is much to be gained by viewing this incarnation of the use of digital content in marketing as part of a wider landscape in which digital content is used in the marketing exchange. Specifically, the term 
digital content marketing has also been used to refer to the marketing of digital content as a commodity (Koiso-Kanttila, 2004; Rowley, 2008), otherwise referred to as the digital goods business (Bradley et al., 2012); typically, this use of the term refers to 'paid for' content in B2C contexts, such as the music and apps sectors. More recently, with the advent of social media, there has been increasing interest in the role of user-generated content in influencing brand reputations, the development of brand communities, and the co-creation of the brand (Christodoulides, 2009; Iglesias et al., 2013; Quinton, 2013). Hence, we summarise key theoretical stances and research findings in the literature review, as a basis for the development of a theoretical exploration of the role of digital content in marketing exchanges which aims to position the findings from this study within a wider landscape.

Returning to digital content marketing in the incarnation that is the focus of this article, this is particularly appropriate in B2B contexts in which companies often form long-term relationships with their customers (Kaplan and Sawhney, 2000), and are increasingly engaged in the co-creation of mutual value (Cova and Salle, 2008; Vargo and Lusch, 2011). In addition, the sales cycle is often long, complex and multifaceted, and involves many participants (Ramos 2009). The ready availability of rich information to all of those involved in the various stages of the purchase process is valued by B2B customers. Consistent with this, eConsultancy and Outbrain's (2012) recent survey confirmed that content marketing and its associated digital marketing techniques now are amongst the key priorities for both B2C and B2B marketers, and recently Google introduced a new algorithm, Hummingbird, that has the potential to promote content and inbound marketing (Lin and Yazdanifard, 2014). On the other hand, only $39 \%$ of brands have an explicit content marketing plan, and $60 \%$ of the content was "dull \& irrelevant", focusing just on product messages (CorporateVisions 2012). Furthermore, research on inbound marketing, in general, or content marketing, more specifically is virtually non-existent.

Accordingly, the specific aim of the research reported in this article is to contribute to understanding of digital marketing in B2B contexts by examining the growing phenomenon of content marketing, from the stance of practitioners in content marketing. The more general aim is, through this study in a relatively unexplored area, to contribute to theory-building associated with the use of digital content in marketing exchanges. More specifically, the objectives of this study are to:

1. Surface and propose a definition of digital content marketing 
2. Enhance understanding of aspects of the strategic decision making associated with content marketing

3. Develop criteria for content selection and development.

4. Offer recommendations regarding future practice in B2B digital content marketing

5. Propose and discuss a holistic framework for the use of digital content in marketing exchanges

The next section of this article presents a review of the published literature on digital content marketing, and summarises relevant theoretical and empirical foundations. Then, the interview-based methodology is outlined. Findings are reported next, in three sections that align with the first three objectives. Finally, the Discussion and conclusions section summarises the research findings and discusses them with reference to prior research and theory, offers recommendations for practitioners and researchers, and proposes a holistic framework regarding the use of digital content in marketing exchanges

\section{Literature Review}

\subsection{Insights into B2B digital content marketing}

There has been no prior academic and peer reviewed research specifically into digital content marketing. However, there have been several surveys by well-regarded marketing research agencies (Handley and Chapman 2011; CorporateVisions 2012) and books that offer advice on digital content marketing (Handley and Chapman 2011; Wuebben, 2012; Rose and Pulizzi 2011). This section will use these sources to explore the defintions of digital content marketing currently in circulation, and some of the key practitioner debates.

\section{Definitions}

The notion of 'content' has its root in the publishing world where words, images and motion graphics have to be sufficiently interesting for the target audience to seek out the publishing platform whether it is a newspaper, magazine, TV or radio channel. However, the concept of content as used in a B2B digital content marketing is less familiar, and hence less clearly defined. For example, Handley and Chapman (2011, p.21) define content as "anything created and uploaded to a website: the words, images or other things that reside here". Halvorson and Rach (2012, p.13) suggest that content is "what the user came (to your website) to read, learn, see or experience”, and Wuebben (2012, p.5) sees content as the key 
component to telling a brand's story "the story of your product or service and propels your brand into the hearts and minds of your prospect, customers and others".

The next important step is consideration of how these notions inform definitions of content marketing. Pulizzi and Barrett (2008, p.8) proposed one of the first definitions of content marketing: "the creation and distribution of educational and/or compelling content in multiple formats to attract and/or retain customers”. Later, Rose and Pulizzi (2011, p.12) suggested: "content marketing is a strategy focussed on the creation of a valuable experience”. Others (Halvorson and Rach 2012; Scott 2011; Bloomstein 2012; Odden 2012) each suggest variations which give the topic a slightly different focus. M. Silverman (2012, p.14) concludes that the purpose of content marketing is to "draw in leads and supplement brand credibility", whereas Godin (2007, p.34) simply remarks that content marketing "is the only marketing left".

\section{Character}

Various commentators have suggested that content marketing represents a change of role for B2B marketers, and associate it with inbound marketing, publishing and story-telling. They claim, for example, that as a form of inbound marketing, content marketing requires a change of mind-set from a 'broadcast' mentality, where brands broadcast a one-way stream of product-based selling messages hoping to 'interrupt' the recipient from whatever they are doing. Rather, organisations need to adopt an 'inbound' approach (Halligan and Shah 2010; Odden 2012) whereby customers actively seek out a brand because it provides them with relevant, engaging content which educates or entertains them. Odden (2012) suggests that customers are now expecting brands to invest in their relationship with them before they get into a purchase scenario. Jefferson and Tanton (2013) agree that a paradigm change in marketing philosophy is required, and suggest that this involves a shift from selling to helping, which will only be achieved if organisations commit to this and develop the necessary skills.

Another aspect of being a content marketer, it is suggested, is the need to take on and learn the role of publisher. As Baer (2012) suggests: "all companies now find themselves in two industries: the business they are actually in, and the publishing business". An important characteristic of publishers is that they carefully identify and define target audiences and consider what content is required to meet their needs (Scott, 2011). According to Rockley and 
Cooper (2012, p.56), this is a substantial cultural shift for many B2B organisations since most corporate marketing is structured: "in order to create content around products and services rather than from a publishing perspective which emphasizes the customer's interests". Many authors and commentators suggest that a core purpose of content marketing is to tell the 'story' of the brand rather than simply to broadcast product based messages to customers and prospects (Bhargava 2012; Halligan and Shah 2010; Pulizzi and Barrett 2008; Pulizzi 2012a; Signorelli 2012). Yet industry surveys suggest that too much of B2B brands' website content is still focussed on company, product or services (Corporate Visions, 2012). The key point of developing a B2B brand's story is to differentiate it from its competitors: " differentiate means telling a different story (to that of your competitors) - not the same story told incrementally better" (Rose and Pulizzi 2011, p.76).

\section{Objectives}

Content marketing objectives must form part of a defined content strategy, defined by Bloomstein (2012, p.101) as: "the practice of planning for the creation, delivery and governance of useful, usable content". The key objectives for content marketing as identified by Rose and Pullizzi (2011) are: brand awareness or reinforcement; lead conversion and nurturing; customer conversion; customer service; customer upsell; and passionate subscribers. Interestingly, these objectives are very similar to the objectives for social media marketing in small and medium sized B2B brands as observed by (Michaelidou et al. (2011), perhaps as a result of their common foundations in the creation and sharing of digital content. Rose and Pulizzi (2011) also propose an 'analytics pyramid' or hierarchy of objectives, with the first level being suitable for the analytics team, the second level for reporting managers, and the top level for top level management. In a recent content marketing study, lead generation (51\%), brand awareness (38\%) and thought leadership (34\%) were cited as the main objectives (B2B Magazine, 2012).

Building a trusted authority position is widely mooted as one of the primary drivers for the success of content marketing (Pulizzi 2012a; Fill 2009; M. Silverman 2012; Scott 2011). Usefully, Peppers and Rogers (2011) identify the four key elements of a content marketing strategy that could enhance trust: shared values (with the customer); interdependence (mutual value in the relationship); quality communication; and, non-opportunistic behaviour. An approach that incorporates these elements is particularly useful for B2B brands with their wider decision-maker involvement and extended purchase timescales. 


\section{Content selection}

Many commentators agree that the key success criteria for content in content marketing scenarios is that it should be in some way great (Pulizzi and Barrett 2008), remarkable (Halligan and Shah 2010) or awesome stuff (Handley \& Chapman 2011), in contrast with standard selling messages. Halvorson and Rach (2012) suggest that content is more or less worthless unless it supports a key business objective and fulfils customer needs, whilst Davis (2012, p.23) argues that: "you need to create content that your audience wants and needs. Often that content will have little to do with the actual products you sell and more to do with the audience you are looking to attract". Davis proposes the 'virtues of valuable content' as being the confluence of frequency, quality and relevance. Jefferson and Tanton (2013) point out that content needs to vary with the platform, with, perhaps Facebook content being funny, beautiful or inspiring, whereas newsletter content should be newsworthy. However, as is evidenced in Corporate Vision's survey (2012), many commentators suggest that B2B brands are missing these messages, and still consider content marketing as simply another opportunity to communicate product driven selling messages rather than solving the audience's problems (Wuebben 2012; Pulizzi and Barrett 2008; Handley and Chapman 2011; Stelzner 2011).

\subsection{Theoretical and empirical foundations}

Whilst research on digital content marketing in the sense used in this study is extremely sparse, there are established bodies of theory and/or research in a number of related areas, including B2B buying processes, B2B brand building, information quality, and other aspects of the use of digital content in marketing exchanges. We draw insights from these areas to build a theoretical platform from which to better understand and elucidate the nature of B2B digital content marketing.

\section{B2B Buying processes}

B2B buying processes are characterised as multi-stage and complex, involving many decision-makers. Marketers' objective is to move potential customers through the prepurchase stage to the purchase stage, and then to further assist customers in the post-purchase stage (Harrison-Walker and Neeley, 2004). The post-purchase stage is important, as B2B purchasing managers tend to form strong bonds with those suppliers who satisfy both the firm's organisational needs as well as the purchasing manager's personal needs (Tellefsen, 
2002). In addition, there is evidence that whilst B2B buyers are influenced by information from numerous sources, they frequently use the internet as their initial source of information (McMaster, 2010). Indeed, Adamson et al. (2012) found that B2B customers typically completed around $60 \%$ of a purchase decision before any conversations with a supplier.

\section{Brand building, buying and trust in $B 2 B$ markets in the digital age}

Acknowledging that content marketing commentators view brand awareness and the creation of a trusted status as key objectives of content marketing, we turn to B2B branding theory. Traditionally, branding was regarded as superfluous in the B2B context, with the focus being on the dedicated sales force (Kotler and Keller, 2006; Leek and Christodoulides, 2011;). However, brand building has become increasingly important for B2B companies, especially for those companies in worldwide, commoditised technology markets where the brand is a signifier for trust (Kotler and Pfoertsch, 2006). A better brand reputation has been found to give the buyer a greater feeling of assurance of the product quality, which leads to a greater willingness to pay a price premium (Bendixen et al., 2004), and confidence that suppliers will stay the course of a long customer relationship (Glynn, 2012). In particular, it is recognised that the corporate brand has a fundamental role in the creation of sustainable relationships between an organisation and its multiple stakeholders (Balmer and Gray, 2003; Schwaiger and Sarsted, 2011). Accordingly, B2B brand owners are becoming more proactive in managing their digital brand presence. Yet, in this endeavour they face two key challenges. First, in digital environments trust is both important in engaging customers in remote locations, and more difficult to achieve (Ibeh et al., 2005; Li et al., 2011). Secondly, with the advent of growing participation in social media, brand reputations are more vulnerable, and indeed, some would argue that the more active and interested the customer community associated with a brand, the greater the chance that the 'ownership' of the brand identity is contested (McCarthy et al., 2013). Brand owners may have no option but to acknowledge that they are losing control of their brands and to view brand-building as an interactive process in a conversational enviroment (Vallaster and Lindgreen, 2011) and to empower customers in the co-creation of brand meaning (Christodoulides, 2009) and value (Inglesias et al., 2013). In many instances, especially in B2C social media contexts, this is associated with co-creation of the content on the brand's website or social media presence, and hence B2B marketers, for whom brand reputation is pivotal to long-term relationships migth usefully consider ways to develop a more collborative approach to content development. 


\section{The use of digital content in marketing exchanges}

Digital content is used in a variety of different ways in marketing exchanges. In this article we focus on the relatively new phenomenon of B2B digital content marketing, in which the digital content is typically used as an inbound marketing technique to pull customers to the website, and to potentially create brand community dynamics associated with the website. Typically, such content is provided free by the organisation in order to promote their products and services, and more widely to cultivate relationships with the other organisations that are their customers; the content might be referred to as 'non-paid' content.

However, the term 'digital content marketing' has been used by other authors (e.g. KoisoKanttila, 2004; Rowley, 2008), in a rather different context, to refer to the trading of digital content or goods over the Internet, where both the products and their delivery are digital (Koiso-Kanttila, 2004). Bradley et al (2012) refer to this as the digital goods business. The digital goods business is typically concerned with 'paid content', such as dating services, digital music, and online newspapers. Interestingly, and of relevance to this research, KoisoKanttila (2004) comments that in this context, the term 'digital content' is widely used in industry analysis, whilst the term 'digital product' is employed in the academic literature. All of the major seminal works in this area are essentially theoretical (Bradley, et al, 2012; Koiso-Kanttila, 2004; Rowley, 2008). In addition, all comment on the lack of research into digital content marketing. Nevertheless, they do raise some interesting issues which are revisited in the Discussion and conclusions, such as the difficulty in fixing notions of value in relation to digital content and its consequences, the notion of value in use (Rowley, 2008), the different roles of content in different business models (Bradley et al., 2012), and the key characteristics of digital content (Koiso-Kantilla, 2004; Rowley, 2008; Wolk and Theysohn, 2007). In addition, Wolk and Theysohn (2007) draw attention to the role of content in driving traffic to a website.

Oestreicher-Singer and Zalmanson (2013), an interesting recent contribution in the information systems literature, propose that social computing/media has the potential to cause a paradigm shift in the online content industry, and argue for a strategic approach that makes

the social experience central to the content websites' digital business strategy. This acknowledgement of the importance of social media as an environment for the creation of user-generated content is acknowledged by many other authors, and has been discussed in relation to its potential influence on brand reputations, the development of brand 
communities, and the co-creation of the brand (Christodoulides, 2009; Iglesias et al., 2013; Quinton, 2013). Thus, there is a third type of digital content marketing, where, unlike in the two categories discussed above, the content is not produced by the organisation, but by its customers or other users of their web-site; such 'social content' (Oestreicher-Singer and Zalmanson, 2013) has a pivotal role in building and maintaining marketing relationships between the organisation and its customers, and also, particularly in B2B contexts, supports sharing and evolution of customer knowledge (Rowley, 2002).

Finally, whilst for ease of exposition the three types of digital content marketing have been distinguished from each other, it is important to acknowledge the importance of hybrid or 'freemium' models, in which a website offers most of its content for free, but restricts access to some premium features to fee-paying customers, or those prepared to exchange their contact details for access to the premium content.

\section{Content and information quality}

Finally, recognising that content is information, we look to the information quality literature for insights into how users evaluate the usefulness of information. According to Hilligoss and Rieh (2008, p.1477): “information quality refers to people's subjective judgment of goodness and usefulness of information in certain information use settings with respect to their own expectations of information or in regard to other information available”. Further, Rieh (2002) proposes that information quality has five facets: usefulness, goodness, accuracy, currency and importance. More specifically focusing on web content, (Fink-Shamit and BarIlan (2008) suggest that in their assessment of information quality, users consider the credibility of content, credibility of the site, predictive relevance, and veracity. Authority, or the reputation of the source or the author, is also widely cited as an important factor when evaluating information on the web (Freeman and Spryrikiadis, 2004; Eysenbach and Kohler, 2002; Tillotson, 2002; Fink-Shamit and Bar-Ilan, 2008).

\section{Methodology}

\subsection{Research approach}

B2B digital content marketing is in a relatively early stage of development, and the knowledge base is dominated by advice from practitioners and consultants. Therefore, an inductive approach, informed by an interpretive stance and executed using a qualitative methodology has been adopted for this study. Such an approach is useful for understanding 
and developing rich descriptions of interviewees' attitudes, perceptions and behaviours (Bryman and Bell, 2011; Saunders et al., 2009), and may act as a basis for theory building. In addition, Daymon and Holloway (2011) suggest that qualitative research techniques are useful when gathering data from professionals such as marketing communications practitioners. More specifically, the method of data collection was semi-structured interviews. Kvale and Brinkman (2009) suggest the interview is a 'conversation'; interviews are useful, in the context of this in-depth, exploratory study, to illustrate what is happening within the subject area and lead to new insights (Saunders et al., 2009).

\subsection{Key informants}

Key informants were identified and recruited through professional networks. One of the researchers is a practitioner in the digital marketing area, and was able to make use of his experience, professional connections, and credibility in this area, to encourage high profile experts to participate in the study. Key informants were selected on the basis of their ability to comment on current practice and challenges in digital content marketing. This might be described as a purposive sample (Silverman, 2010), constituted to draw on the specific knowledge of the participants (Braun \& Clarke 2006). Participants all held senior positions in their organisations and worked in B2B markets in one of the following sectors: technology hardware and software, recruitment, business and professional services, marketing services, and recycling and renewables. These sectors include both manufacturing and service sectors and are representative of the opportunities and challenges faced by B2B businesses in utilising content marketing. Companies based in the UK, USA and France are included. Informants can be divided into companies using digital content marketing (users), and those, typically in marketing services companies, (advisors), who are advising other companies on their digital marketing strategies. The number of participants is consistent with that used in other qualitative studies that require informants from business backgrounds (e.g.Veloutsou and Taylor, 2012; Wallace and De Chernatony, 2007). Table 1 shows the profile of the research sample.

\begin{tabular}{|l|l|l|l|l|}
\hline Interviewee & $\begin{array}{l}\text { User (U) or } \\
\text { Adviser (A) }\end{array}$ & Job title & Location & Company Activity \\
\hline 1 & U & Operations Director & UK & Translation services \\
\hline 2 & A & President / Founder & USA & Marketing services \\
\hline 3 & A & President & USA & Marketing services \\
\hline 4 & A & President/Speaker & USA & Marketing services \\
\hline
\end{tabular}




\begin{tabular}{|l|l|l|l|l|}
\hline 5 & U & $\begin{array}{l}\text { Vice President of } \\
\text { Thought Leadership } \\
\text { and Marketing }\end{array}$ & France & Recruitment \\
\hline 6 & A & Chief Executive Officer & USA & Marketing services \\
\hline 7 & U & $\begin{array}{l}\text { Senior Director of } \\
\text { Global Marketing }\end{array}$ & USA & Software \\
\hline 8 & U & $\begin{array}{l}\text { Chief Marketing } \\
\text { Officer USA }\end{array}$ & Software \\
\hline 9 & U & Head of Marketing & UK & Recruitment and \\
\hline 10 & U & $\begin{array}{l}\text { Head of Branding and } \\
\text { Corporate Publications }\end{array}$ & France & $\begin{array}{l}\text { I.T. Hardware and } \\
\text { software }\end{array}$ \\
\hline 11 & U & $\begin{array}{l}\text { Content Marketing } \\
\text { Director USA }\end{array}$ & Software \\
\hline 12 & A & $\begin{array}{l}\text { Chief Content Officer } \\
\text { Chief Operating Officer }\end{array}$ & UK & $\begin{array}{l}\text { Marketing \& training } \\
\text { services }\end{array}$ \\
\hline 13 & A & Uarketing services \\
\hline 14 & U & $\begin{array}{l}\text { Vice President of } \\
\text { Marketing USA }\end{array}$ & Software and services \\
\hline 15 & U & UK & Renewables \\
\hline
\end{tabular}

Table 1 - Profile of Key Informants

\subsection{Interview design and data collection}

Semi-structured interviews were chosen as they provide a framework for the conversation between the interviewer and the interviewee, whilst allowing flexibility (Bryman and Bell, 2011), and scope to pursue interesting emergent topics (Liedner, 1993). An interview guide was developed with nine open-ended interview questions, which align with the research objectives as shown in Table 2. Between four and six additional prompts per question were included in the interviewers' version of the guide, in order to support the researcher in ensuring that all aspects of the question had been explored.

The interview guide was pre-tested and then piloted with by a research/practitioner working in a role similar to the proposed interviewees to establish content validity (Saunders et al. 2009). This pilot interview confirmed that the questions were relevant and comprehensible and that the interview length was appropriate. All interviews were conducted within a onemonth period, using Skype. A week prior to their interview, interviewees were sent a copy of the interview guide showing the nine interview questions. Each interview took between 40 and 50 minutes. Interviews were recorded and transcribed. 


\begin{tabular}{|c|c|}
\hline \multicolumn{1}{|c|}{ Research objective } & \multicolumn{1}{|c|}{ Interview question } \\
\hline $\begin{array}{l}\text { Surface and propose a definition of } \\
\text { content marketing }\end{array}$ & $\begin{array}{l}\text { 1. What is your definition of content } \\
\text { marketing? }\end{array}$ \\
\hline $\begin{array}{l}\text { Enhance understanding of aspects } \\
\text { of the strategic decision making } \\
\text { associated with content marketing }\end{array}$ & $\begin{array}{c}\text { 2. How are you selecting the content marketing } \\
\text { distribution channels that you are currently } \\
\text { using? }\end{array}$ \\
\hline & $\begin{array}{l}\text { 3. What marketing objectives have you set for } \\
\text { your content marketing? }\end{array}$ \\
\hline & $\begin{array}{l}\text { 4. How are you justifying the use of content } \\
\text { marketing within your business? }\end{array}$ \\
\hline & $\begin{array}{l}\text { 5. How are you using content marketing to } \\
\text { increase the trusted status of your brand? }\end{array}$ \\
\hline $\begin{array}{l}\text { 6. What do you consider to be the significant } \\
\text { internal or external obstacles to content } \\
\text { marketing success? }\end{array}$ \\
\hline 7. What measures do you use to evaluate the \\
effectiveness and ROI of your content \\
marketing?
\end{tabular}

Table 2 - Interview questions mapped against research objectives

\subsection{Ethics}

The subject matter of this study is not contentious and unlikely to be subject to any corporate or professional ethics committee jurisdiction (Bell, 2010), or to be business critical and, thus pose any risks to participation. All responses were regarded as confidential and no attribution was made of any comment to a named individual. Participation in the interviews was voluntary. All interviewees were read a pre-prepared interviewee advisory statement outlining the purpose of the research and offering a copy of the transcript. Any question be skipped if interviewees preferred (Bell, 2010), and participants were offered the opportunity to withdraw their contribution up to a given date prior to submission of the final report (Saunders et al., 2009).

\subsection{Analysis}

Thematic analysis of the interview transcripts was conducted in order to identify themes and perspectives (Creswell, 2009). Given the researchers' familiarity with the topic, manual analysis of the transcripts, using standard office productivity software was used to support an intuitive approach to the process (Daymon and Holloway 2011). The Braun and Clarke 
(2006) thematic analysis checklist was utilised throughout the analysis phase to maintain consistency of approach. Transcripts were edited to remove extraneous comment and then themes were colour-coded. Finally, colour-coded responses were collated into individual Microsoft Word documents for analysis and comparison. Care was taken to avoid selecting data which matched the researchers' pre-conceptions and avoid bias (Kvale and Brinkmann, 2009).

\section{Findings}

\subsection{Definitions and essence}

\section{Content}

Commencing with defitions of content, P7 offered a definition, which summarised the stance taken by most participants:

"Any kind of information in many different types of digital formats, such as video, written texts graphics, slides.... any kind of digitally presented information delivered essentially over the Web, over the internet or in any kind of social network."

This is further amplified by P12's comment that content is "anything that you create or share that tells your story".

In order to provoke further reflection on the nature of content, the interviewer proposed a typology of content types (social media content, web page content and value-add content) and invited views on this typology. Of the eleven participants who expressed an opinion on this typology seven (P1, P2, P3, P5, P9, P10, P14) agreed that it was a useful and accurate reflection of the types of content that B2B marketers produce and would be a useful model. Other useful comments included:

"I think that (the typology) captures it pretty succinctly but they're not all mutually exclusive” (P9)

“maybe 'format' and then 'purpose' of content might be two ways to think about it too" $(\mathrm{P} 8)$

\section{Content marketing}

Participants offered a wider range of comments on the definition and nature of 'content marketing'. Whilst there was a reasonable level of consensus over the scope and nature of content marketing, a number of different perspectives were evident. The most concise definition was offered by $\mathrm{P} 2$ : 
"Valuable, compelling and relevant content on a consistent basis to attract and retain customers through information that they actually want to receive."

However, many participants suggested that since content marketing was a relatively new term the topic was marked by "relative immaturity" (P5) and a lack of consistent definitions. Some participants explicitly stated that the definition of content marketing was not well understood by marketers:

"for me... (it) is perhaps the most poorly defined sub-segment of marketing" (P15).

"I think there's a fair amount of confusion around it" (P8)

"we're still at a very early phase of this content marketing and people barely understand it”. (P3)

Moving onto related issues regarding the nature of content marketing, several participants commented on the growing importance of inbound marketing. They acknowledged that customers are no longer willing to be subjected to "being interrupted by brands" (P2), and that this was leading to a significant increase in the adoption of inbound marketing techniques (P2, P4, P7, P8). Inbound marketing where "customers actually want to receive our marketing" (P2), was cited as a key driver of content marketing adoption (P2, P6, P8). Indeed, inbound and content marketing were seen by some as inextricably linked, if not interchangeable (P6, P8).

Many participants referred to the notion of brands behaving like publishers and telling stories about their brands to engage customers in dialogue. Digital marketing techniques are perceived as enabling marketers to converse with customers; as P11 observed "you no longer need to have a television station or a radio station to become a publisher". However, it was noted that a key success factor for a "brand as a publisher" (P2, P8, P11) was to be able to "tell a good story" (P2, P3, P5, P11, P12, P13). P11 suggested that the definition of a 'brand as publisher' was:

"Being a story teller and engaging an audience, customers and prospective customers in the story in a meaningful way that's about the brand, not about the company."

However, P2, P8 and P10, shared the view that with technology easily available and low barriers to entry, publishing digital content could be construed as being too easy, leading to a lack of clear objectives in digital content marketing; P2 commented: "the majority of the companies we talk to cannot clearly articulate why they are creating content". 


\subsection{Strategic aspects}

\section{Objectives}

The study sought to understand how participants configured their content marketing objectives within the context of a content marketing plan or strategy. Consultants/advisers were keen for client brands to develop a separate or stand-alone content marketing plan (P2, P6, P12 and P13). On the other hand, only P5, amongst the clients, had a separate content marketing plan, with all other client participants who responded explicitly to this question saying that it formed part of their overall marketing plan (P 6, P7, P9, P10, P14).

Many participants cited several objectives for their content marketing. Lead generation was the most commonly mentioned objective (P2, P3, P5, P6, P10, P12, P15) with P5 commenting,

"(we have a) pretty heavy sales orientated set of objectives."

Aligned to this, P1 and P6 also identified a key objective as generating traffic to their websites.

Brand awareness or brand building (P1, P2, P7, P9, P10, P11) was also an important objective, suggesting that a lot of practitioners were viewing content marketing as a substitute for advertising as a means of distributing their brand messages. As P7 stated,

"our content marketing objectives are quite specifically intended to reach the audience of people that don't know exactly what we do".

However, there was also evidence that participants were keen to use content marketing as a means of building a thought leadership position for their brands and enhancing the brand's status as a trusted brand (P2, P6, P10, P12, P14). Some participants (P8, P9, P14) felt that it was important for their brands to take a strong position on key market issues and be prepared to discuss them, even if their position was contentious. As P8 summarised,

"you need ... to take a stance and have an opinion about things, even if not everyone agrees with you”.

Participants agreed that 'trust' was an important attribute of their customer relationships, and noted that trust is earned over time and requires consistent behaviour (P2, P6, P8, P11). As P2 suggested:

"Content is a promise to your customers and if you don't keep that promise in some kind of a regular format, they'll forget about you'. 
Participants identified several key characteristics of the content marketing approach that they believed contributes to brands status as a trusted source. They emphasised strongly that content marketing should not try to explicitly sell or use selling language (P 2, P6, P8, P9, P10, P11). Overt selling language is easily discernible by customers and prospects and diminishes the perceived value of the content. P6 also noted,

"If you can take that position where you're giving them some great content and not asking for the sale, not only will you build credibility and trust, but you're going to be the one who gets the business down the road".

However, adopting this stance can be a challenge for B2B content marketers whose executive management still perceive content marketing in the same way as other marketing methods. As P9 observed,

"I'm still battling (to) get them to accept that there doesn't have to be a sales message at the end of everything".

Participants also expressed their views on the type of content that is most useful in building trust. There was a general agreement that long form content in either text or video formats were most useful. The most cited content format for engendering trust was market research and reports (P2, P5, P6, P9, P11) whereby the brand commissions its own original research into a key market issue. P11 summarised several participants' views,

"(research) has by far been one of the most successful types of content...in building trust to (sic) our brand".

However, P11 also noted that even original research as a content marketing tool was potentially being undermined by its own popularity, "it seems that everyone does it now, so how trusted can it be?" Other long form text content such as case studies (P1, P3, P14), whitepapers (P3, P9, P12) and E-books (P4, P9, P12) are also considered important in allowing a brand to expound its view on issues important to customers and prospects. Other formats such as webinars, blogs and video were also suggested as key trust building tools.

\section{Justifying investment}

Several participants argued the case for content marketing on the basis that a large proportion of B2B purchase decisions are being made before the customer makes direct contact with the vendor. However, many had experienced difficulties in persuading executive management to commit to investment in content marketing, and felt that executive management struggled to understand the concept of content marketing and hence there was a need for internal 
education (P3, P5, P11, P14). In particular, B2B content marketers face challenges in persuading executive managers to view content marketing differently and not to apply established campaign-based criteria. As P13 said,

"It's not campaign led. Content marketing is a culture not a campaign."

P2 took the view that the time that content marketing activities take to deliver measurable results can be can be longer than other marketing activities ("expect nothing to happen for the first six months") and that this mitigated against executive management's understanding of the value of content marketing to the customer and the brand. Other participants argued the case with their managers by suggesting "advertising's not working any more” (P5). P5 and P11 considered appealing to the ego of executive management by positioning content marketing not only as a brand builder, but also as reputation builder for them individually by, as P5 suggested, making them into 'internal rock stars'. However, it was widely acknowledged that the most effective way of justifying content marketing is by testing, measurement and showing results, with pilot studies being particularly useful (P1,P2, P3, P6, P7, P9, P10, P12, P13).

\section{Distribution channels}

There was no strong consensus on the criteria for choosing content marketing distribution channels. Five participants identified that media choices were made on the basis of where targeted recipients were "likely to congregate" (P13), which may not necessarily be where brands hope or expect them to be because,

"customers are now in charge and they'll tell you what and how they want to consume it" (P11).

Others suggested that the media which drove most engagement (P1, P12) or those that were most affordable (P10) were most likely to be selected. Two suggested that the plethora of channel choices was both a benefit and an obstacle (P3, P12). Finally, P7, P8, P9 and P12 emphasised the importance of on-going testing of content distribution channel efficiency. 
P2 reflected the views of others, in noting the importance of setting quantifiable goals for content marketing,

"if you don't put a number to it of some kind, you never know when you hit the objective”.

P11 and P13 elaborated further, pointing out that it was important to understand the customer journey that content marketing was seeking to influence before metrics could be selected and applied. Nevertheless, many of the participants were utilising the same metrics that they use for other marketing activities. Four participants (P3, P7, P9, P11) referred to the groups of metrics recently identified by the Content Marketing Institute: consumption, lead generation, sharing and sales. However, P11 cautioned against setting too many objectives noting,

"I'd rather have two KPIs that I can do something about than thirty KPIs that mean nothing to me."

Web analytics were also identified as key to the measurement of content marketing efficacy (P3, P12, P14). Other primary metrics used by participants included bottom line profit or sales (P1, P11), cost per new customer (P8) or the number of backlinks generated by the content (P9).

Obstacles to success

All participants had faced challenges when implementing content marketing. The most significant challenge for seven participants (P2, P3, P7, P8, P9, P10, P12) was related to the cultural shift associated with content marketing. P2, P3, P7 and P9 faced the problem that their brand's executive management, 
“want to see highly promotional pieces of content coming out of marketing” (P7).

As $\mathrm{P} 3$ commented too many B2B marketers are,

"in the traditional marketing mind-set where they think this content needs to be selling."

P4 and P6 elaborate further,

"they end up just talking about their products and services because that's what marketers have done for ages" (P4)

"they (B2B brands' executive management) are in love with what they do, they're in love with their products and they want to tell the world about it." (P6)

P8 and P12 suggested that brands struggle to understand that content marketing is a significant cultural commitment and not simply a new tactic or single campaign. P10 added that,

"this way of working calls on skills that marketers and communicators inside companies don't normally have."

Time lag to delivery of measurable results was cited by P2, P3 and P10 as an obstacle to engaging their executive management, a situation often exacerbated by the long purchase cycles that are common in $\mathrm{B} 2 \mathrm{~B}$ markets.

Time and budget resources were, not unexpectedly, posed as real obstacles to content marketing implementation (P1,P6, P7, P10, P14), as was access to, or engagement of, subject experts (P1, P5, P6, P11, P14) who were potential content authors, but were not always available, due to time pressures. The rising popularity of content marketing has also created 
significant clutter within the markets of several participants. Both P1 and P11 complained that low barriers to entry for the creation and publishing of digital content makes it difficult for their high quality content to "get through all of the bad content" (P11). Other assorted obstacles included: unwillingness to engage in a proper planning process (P2); legal compliance processes $(\mathrm{P} 3)$; and, the perception that high quality content was perceived as "giving away the source of our thought leadership or expertise for free" by the brand's executive management (P7).

\subsection{Content selection and development}

\section{Selecting content types}

The most consistently suggested content selection criteria was that of 'shareability', that is, brands seek to create content with the expressed intention of it being readily and freely shareable (P1, P5, P6, P7, P8, P12, P14). In addition, there was agreement that content should be created according to the needs of the customer or intended recipient and that those needs must be defined by research and testing (P9, P10, P11, P12). As P11 explained,

"you have to know who the right people are before you create any piece of content....... I think one of the reasons why that happens (ineffective content) is because the content marketer or the marketer just doesn't understand who he's trying to reach and what their pain points and what they're interested in."

P12 elaborated further suggesting that content selection criteria should be defined as,

“ meeting the needs of your customer first, and not about does it further our agenda". P1 and P6 identified that content must be useful and relevant to the customers or prospects (see also later on 'Great' content), which P11 and P12 further characterised as solving a problem or addressing a customers' pain points. Creating content that addresses a 'hot' or trendy issue in the market place was considered important (P6, P11). P11 mentioned looking at competitors' content creation as a guide to the types of content that their brand should create.

A key facet of B2B marketing is the targeting of messaging to prospects and customers dependent upon where they are in their buying cycle. Most participants agreed that content should match a buyer's position in their customer journey (P1, P5, P6, P7, P8, P9, P11, P12, P13, P14); P12 summarised this, 
"I think it's a matter of knowing what will resonate with them at various stages of the buying cycle."

However, many felt that undertaking this journey-based targeting of content was 'difficult' (P1, P5, P6, P10), with P10 commenting, “we're not quite sure about where they're falling in the purchase cycle". Others noted that such targeting requires continual testing to ensure accuracy (P7,P8, P9, P11). P5 and P10 also observed that B2B buying cycles are often long and this makes journey-based targeting more difficult.

\section{'Great' content}

When asked what they perceived to be 'great' or effective content, participants Talked in terms of the content being of value to customers. They saw effective content as being that which engages and is interesting to the audience (P1, P2, P6). In particular, great content adds value by making helping the audience to do something better, or by solving a specific problem or pain they have in their professional life (P1, P2, P3, P6, P9, P12, P15):

"(the) best way to do that is to provide something of value, content that's going to help them to do something better, improve something in their lives.” (P6)

"my audiences have always responded best to content that creatively and succinctly smoothes an unspoken pain.” (P15)

In summary, $\mathrm{P} 2$ suggested that B2B marketers should simply make the content "valuable, relevant and compelling."

These customer centric attitudes were balanced by the recognition of the need deliver some kind of positive business outcome (P2, P5, P11). Participants argued that making content useful and valuable and not persistently selling the brand's products would ensure that content would be more shareable (P2, P5, P7, P9, P11) and that this would be the "social proof that your content is great” (P2).

Some participants (P1, P8, P12, P13) suggested that a potential measure of the quality of content could be whether the audience would be prepared to pay for it. P12 said,

"will your customer thank you for it.... will they pay you for it, will they thank you for it?"

At the very least, several participants emphasised the audience's role in evaluating content 'greatness'. P11 suggested that it is, "the people consuming the content (that) make it great". P4 commented in the language of the content, "the content has to use the language that those 
people use" whilst P15 observed that truly effective content marketing is grounded in a brand "viewing itself through the customer's eyes." P12 suggested that brands should aspire be become a content brand, and not just a brand that creates content.

\section{Discussion and conclusions}

Summary and discussion of empirical findings

In the face of evidence that B2B purchasers are becoming increasingly reliant on the Internet to gather information during the early stages of the buying process (Adamson et al., 2012; CorporateVisions, 2012), content is playing an increasingly important role in B2B buying processes and it is important that organisations develop their content marketing strategies accordingly.

This research is the first to explore digital marketing practitioners' views on the nature of, and processes and challenges associated with B2B digital content marketing.

First, based on our thematic analysis of participants' comments on the nature of content marketing, we offer the first empirically grounded conceptual definition of digital content marketing:

" $B 2 B$ digital content marketing involves creating, distributing and sharing relevant, compelling and timely content to engage customers at the appropriate point in their buying consideration processes, such that it encourages them to convert to a business building outcome."

This definition offers a more open definition than the much-quoted practitioner definition offered by Pulizzi and Barrett (2008), in that it goes beyond creating and distribution of content to include content sharing, is more specific about the key characteristics of content, makes reference to the buying process, and is open as to the potential business outcome. An important point is that being in a position to engage customers at the relevant point in their buying consideration relies upon organisations having a clear view of their buying cycle, which, in turn, depends on continuing engagement with the customer. On the other hand, interestingly, and arguably short-sightedly, practitioners, in their rhetoric about acting as publishers, neglect to consider user-generated content, and the value that this might have in community and brand-building. 
Secondly, the study provides some empirical evidence in support of the views promulgated by previous commentators:

1. Participants concurred that a key rationale for adopting content marketing was that purchasers were increasingly passing through a significant part of the buying process before making contact with suppliers (Halligan and Shah 2010; Odden 2012).

2. Participants recognised the primacy of focusing content on the needs of the audience (Halvorson and Rach 2012), and the importance of avoiding recycling of selling messaging in the guise of content (Stelzner. 2011).

3. Participants talked in terms of adopting a publisher's mindset, with its focus on understanding audience needs, and story telling (Baer, 2012; Davis, 2012; Handley and Chapman, 2011; Wuebben, 2012).

4. Although many content marketers did not have a separate content marketing strategy, as recommended by Bloomstein (2012), they were able to identify objectives for their content marketing. Typically, they identified several objectives, key amongst which were lead generation, brand awareness and brand building, offering thought leadership, and achieving trust brand status. This list aligns with a recent survey reported in B2B Magazine (2012) that also identified the primacy of lead generation. On the other hand, it suggests that achieving a trusted brand status is less central than other commentators recommend (Pulizzi 2012a; Fill, 2009; Scott, 2011). There is also some alignment of objectives with research conducted on social media (Michaelidou et al., 2011), arising from common concerns with the creation and, ultimately, sharing of digital content. There is also evidence to support commentators' views that many B2B brands are still viewing content marketing as another opportunity to communicate product driven selling messages (Pulizzi and Barrett 2008; Stelzner, 2011).

In addition, this study offers further insights into the challenges associated with developing an effective digital content marketing strategy. These include:

1. The need for content marketing KPI's and metrics and the development of appropriate dashboards.

2. The challenges associated with recruiting and developing subject experts who were also capable of 'journalistic' story telling, on order to be able to generate good quality content. This aligns with the debate in the information sciences literature on the 
authority or reputation of the source or the author (Tillotson, 2002; Fink-Shamit and Bar-Ilan, 2008).

3. The importance of creating 'great' content, defined as content that helps customers to do something better or to solve a problem. Great content is seen as content that is interesting and of value to customers. These notions align to some extent with the notions of web-based information quality, that suggest, for instance, that information quality has the five facets of usefulness, goodness, accuracy, currency and importance (Rieh, 2002).

4. Challenging the selling mindset of traditional marketing, and leading the culture change in $\mathrm{B} 2 \mathrm{~B}$ organisations, such that the long-term nature of content marketing in supporting reputation and partnership building is recognised by executive management.

In the absence of prior research, other than some useful practitioner surveys that profile the approaches that B2B businesses are taking to digital content marketing, there is plenty of scope for further research into digital content marketing. In particular, practitioners might be interested in case study research that provides exemplars and benchmark studies in different sectors. From a theory development perspective, further exploration of the character of content that is valued by business customers, would benefit from a stronger grounding in previous research on information quality, and its dimensions, coupled with exploration of how judgements of information quality are made in B2B buying and relationship building processes. Such research is likely to explore the roles and behaviour of different stakeholders at different stages in the buying/relationship cycle. In addition, survey based studies, using quantitative approaches would provide useful insights into the range of digital content marketing practices adopted in different sectors, the value that digital content marketing can deliver, and the challenges to be negotiated, and in allowing the developments of measures for key variables, would offer a basis for theory testing.

In their journey to explore and improve their B2B digital content marketing practices, practitioners should:

1. Acknowledge digital content marketing as constituting a paradigm change, from selling to the customer, to helping the customer, and develop an understanding of how this might be achieved through content in the digital channel, 
2. Adopt a strategic approach content marketing that views it as an ongoing cultural stance where the focus is on building an authentic relationship over the longer term, rather than conducting a series of short-term campaigns.

3. Align their content marketing objectives with prioritising building a trusted brand status, over, for example, short term sales or lead generation objectives,

4. Develop an understanding of how, for their business, digital content marketing complements other marketing activities,

5. In selections recognise that good is relevant, compelling and timely, which in turn makes it valuable and useful for the customer

6. Recognise that providing valuable content requires an understanding of customer information needs at different points in time, and at different point in their buying/relationship process.

7. Develop an understanding of the role and effectiveness of different types of content (e.g. social media content, web content, and value-add content), for different audiences.

8. Develop metrics and measurement tools that align with digital content marketing objectives, and include metrics relevant to relationship building, and customer development, taking into account factors such as customer lifetime value.

\section{Towards a holistic theory of digital content marketing}

This section positions B2B digital content marketing within a wider framework that also encompasses other types of digital marketing. First, whilst acknowledging the explanatory value of more specific definitions for the various types of digital content marketing, including that for B2B digital content marketing proposed earlier in this section, we argue that a generic definition that covers all types of digital content marketing is useful. For this purpose, we adapt the AMA (2013) definition of marketing, thus:

Digital content marketing is the activity associated with creating, communicating, distributing, and exchanging digital content that has value for customers, clients, partners, and the firm and its brands.

This definition is intended to encompass all of the different incarnations of digital content marketing. Table 3 summarises these incarnations simply in terms of three key types of digital content marketing. Important points to note are:

1. In this research we have focussed on 'Not-paid for' DCM in the B2B context. Organisations also use this in $\mathrm{B} 2 \mathrm{C}$ contexts where they are seeking to draw 
consumers to their website and brand community. Indeed, in this context, the fremium model, which is a hybrid of 'not paid for' DCM and 'paid for' DCM is widely adopted.

2. In 'paid for' DCM, the focus for the organisation is on achieving sales of the digital product (e.g. music, e-books, apps) and for consumers the focus is on the experience of the digital product and its delivery.

3. Social DCM is differentiated by its focus on user-generated content, but the organisation also has a role in managing the communication in its social media spaces, and in general, to provide community leadership to ensure that value is created through content and interaction for all stakeholders. Again, many social DCM initiatives do not stand alone, but are rather part of wider DCM activity, involving either or both of 'paid for' or 'not paid for' content.

There are two key concepts that lie at the heart of all types of digital content marketing community and value. There is no doubt that both are difficult to achieve, but there are strong theoretical foundations that can be used to inform the further development of a holistic approach to digital content marketing. On community, there is an established literature on brand communities (e.g Fournier and Lee, 2009; Muniz and O'Guinn, 2001) and on online communities (e.g. Armstrong and Hagel, 1996). Recent years have witnessed the advent of online brand communities, as one of the features of branding in the digital age (e.g. Kim et al., 2008) and the notion of brand co-creation in online social spaces (e.g. Hatch and Scultz, 2010). Digital content, whether it be 'not paid for', 'paid for' or social is at the heart of brand building processes. Turning to value, the research reported in this article suggests the importance of the content being valuable and useful to the audience, and helping them to complete a task or solve a problem. Similarly, with 'paid for' content the consumer is likely to be seeking some functional or hedonistic gratification in exchange for their payment. Such stances are confirmed by the theoretical literature on information quality and credibility (Hilligoss and Rieh, 2008; Rieh, 2002). Using the theoretical frameworks in these areas has potential to advance understanding of value in digital content marketing. However, in this endeavour it will be important to acknowledge that the value of digital content is contextual and such that its value in use by different users on specific occasions is difficult to predict in advance (Rowley, 2008). 


\begin{tabular}{|c|c|c|c|c|}
\hline $\begin{array}{l}\text { Characteristics } \\
\text { of DCM }\end{array}$ & $\begin{array}{l}\text { Originator of } \\
\text { content }\end{array}$ & $\begin{array}{l}\text { Originators' } \\
\text { key aim }\end{array}$ & $\begin{array}{ll}\text { Users } & \text { of } \\
\text { content } & \\
\end{array}$ & Users' key aim \\
\hline \multicolumn{5}{|l|}{ Types of DCM } \\
\hline $\begin{array}{l}\text { 'Not-paid for' } \\
\text { DCM }\end{array}$ & Organisation & $\begin{array}{l}\text { Customer } \\
\text { engagement and } \\
\text { building } \\
\text { relationships, } \\
\text { knowledge and } \\
\text { brand } \\
\text { community. } \\
\text { Business } \\
\text { Product } \\
\text { service } \\
\text { purchases, or } \\
\text { contracts }\end{array}$ & $\begin{array}{l}\text { Business client } \\
\text { organisations }\end{array}$ & $\begin{array}{l}\text { Business } \\
\text { purchase } \\
\text { decision-making } \\
\text { Business } \\
\text { intelligence } \\
\text { Consumer } \\
\text { decision-making } \\
\text { and purchase }\end{array}$ \\
\hline 'Paid for' DCM & Organisation & $\begin{array}{l}\text { All of the above, } \\
\text { but in addition, } \\
\text { sales of the } \\
\text { DCM. }\end{array}$ & Consumers & $\begin{array}{l}\text { Positive } \\
\text { experience } \\
\text { regarding the } \\
\text { digital product } \\
\text { and its delivery }\end{array}$ \\
\hline Social DCM & $\begin{array}{l}\text { Brand } \\
\text { community } \\
\text { members }\end{array}$ & $\begin{array}{l}\text { To express } \\
\text { views; } \\
\text { To learn from } \\
\text { the organisation } \\
\text { and other users; }\end{array}$ & Organisation & $\begin{array}{l}\text { Market } \\
\text { intelligence; } \\
\text { Persuasion; } \\
\text { Relationship and } \\
\text { community } \\
\text { building }\end{array}$ \\
\hline
\end{tabular}

Table 4: The types of digital content marketing

\section{References}

Adamson, B., Dixon, M. and Toman, N. (2012), "The end of solution sales", Harvard Business Review, July-August, pp.60-68.

Armstrong, A and Hagel, J. (1996), "The real value of online communities", Harvard Business Review, Vol.74, No.3, pp.134-141.

B to B Magazine (2012), "Content marketing: ready for prime time", B to B Magazine, (September), $\quad$ pp. 4-7, available at: http://www.btobonline.com/pdfs/content_samples_091312.pdf (accessed 23 December 2013) 
Baer, J. (2012), "Why you need to turn your content marketing upside down- convince and convert", available at: http://www.convinceandconvert.com/content-marketing-2/whyyou-need-to-turn-your-content-marketing-upside-down (accessed 23 December 2013).

Balmer, J.M.T. and Gray, E.R. (2003), "Corporate brands: what are they? what of them?". European Journal of Marketing, Vol.37, Nos.7-8, pp. 1064-1092.

Bell, J. (2010), Doing your Research Project, 5th ed., McGraw Hill Eduation,.Maidenhead.

Bendixen, M., Bukasa, K.A. and Abratt, R. (2004), "Brand equity in the business-to-business market". Indutrial Marketing Management, Vol.33 No.5, pp. 371-380.

Bhargava, R. (2012), Likeonomics: the Unexpected Truth behind Earning Trust, Influencing Behavior, and Inspiring action, Wiley, Hoboken, N.J.

Bloomstein, M. (2012), Content Strategy at Work. Elsevier, Waltham, MA.

Bradley, S., Kim, C., Kim, J. and Lee, I. (2012) "Toward an evolution strategy for the digital goods business", Management Decision, Vol.50, No.2, pp.234-252.

Braun, V. and Clarke, V. (2006), "Using thematic analysis in psychology", Qualitative Research in Psychology, Vol. 3 No.2, pp. 77-101.

Bryman, A. and Bell, E. (2011), Business Research Methods, Oxford University Press, Oxford.

Christodoulides, G. (2009), "Branding in the post-internet era", Marketing Theory, Vol.9 No.1, pp.141-144.

CorporateVisions (2012), "Demand Gen Deficit: why your campaigns create hand-raisers, not sales-qualified leads", available at: http://win.corporatevisions.com/rs/corpv/images/CVIQuarterlyReport_Q212.pdf (accessed 23 December 2013).

Cova, B. and Salle, R. (2008), "Marketing solutions in accordance with the S-D logic: cocreating value with customer network actors", Industrial Marketing Management, Vol.37 No.3, pp.270-277.

Creswell, J.W. (2009), Research Design, Sage, Los Angeles.

Davis, A.M. (2012), Brandscaping, Content Marketing Institute, Cleveland, $\mathrm{OH}$.

Daymon, C. and Holloway, I. (2011), Qualitative Research Methods in Public Relations and Marketing Communications, 2nd ed., Routledge, Abingdon.

eConsultancy (2012), Content Marketing Survey Report 2012 in association with Outbrain, available from: http://econsultancy.com/uk/reports/content-marketing-survey-report (accessed 23 December 2013).

Eysenbach, G. and Kohler, C. (2002), "How do consumers search for and appraise health information on the World Wide Web? Qualitative study using focus groups, usability tests, and in-depth interviews", British Medical Journal, Vol.324 No.7337, 573-577.

Fill, C. (2009), Marketing Communications: Interactivity, Communities and Content, Pearson Education, Harlow.

Fink-Shamit, N. and Bar-Ilan, J. (2008), "Information quality assessment on the web - an expression of behaviour", Information Research, Vol.13 No.4, available at: http://informationr.net/ir/13-4/paper357.html (accessing 23 December 2013).

Fournier, S. and Lee, L. (2009), "Getting brand communities right", Harvard Business Review, Vol. 87 No.4, pp105-111. 
Freeman, K.S. and Spryrikiadis, J.H. (2004), "An examination of factors that affect the credibility of online health information", Technical Communication, Vol.51 No.2, pp.239-263.

Glynn. M.S. (2012), "Primer in B2B brand-building strategies with a reader practicum", Journal of Business Research, Vol.65 No.5, pp. 666-675.

Godin, S. (2007), Permission Marketing: Turning Strangers into Friends and Friends into Customers. Simon \& Schuster, New York.

Halligan, B. and Shah, D. (2010), Inbound Marketing, Wiley, Hoboken, N.J.

Halvorson, K. and Rach, M. (2012), Content Strategy for the Web. New Riders, Berkeley, CA.

Handley, A. and Chapman, C.C. (2011), Content Rules. Wiley, Hoboken, N.J.

Harrison-Walker, L.J. Neeley, S.E. (2004), "Customer relationship building on the internet in B2B marketing a proposed typology", Journal of Marketing Theory and Practice, Vol.12 No.1, pp.19-36.

Hatch, M.J. and Schultz, M. (2010). "Toward a theory of brand co-creation with implications for brand governance", Brand Management, Vol.17 No.8, pp.590-604.

Hilligoss, B. and Rieh, S.Y. (2008), "Defining a unifying framework for credibility assessment: construct, heuristics and interaction in context", Information Processing and Management, Vol.44 No.4, pp.1476-1484.

Ibeh, K., Luo, Y.and Dinnie, K. (2005), "E-branding strategies of internet companies: some preliminary insights from the UK", Journal of Brand Management, Vol.12 No.5, pp.355373.

Iglesias, O. (2013), "The organic view of the brand: a brand value co-creation model", Journal od Brand Management, Vol.20 No.8, pp.670-688.

Jefferson, S.and Tanton, S. (2013), Valuable Content Marketing, Kogan Page, London.

Kaplan, S. and Sawhney, M. (2000), E-hubs: the new B2B marketplaces. Harvard Business Review. Reprint no.R00306.

Kim, J.-W., Choi, J., Qualls, W., and Han, K. (2008) "It takes a marketplace community to raise brand commitment: the role of online communities", Journal of Marketing Management, Vol.24, Nos. 3-4, pp. 409-431.

Koiso-Kanttila, N. (2004), "Digital content marketing: a literature synthesis", Journal of Marketing Management, Vol. 20, pp.45-65

Kotler. P. and Keller, K.L. (2006), Marketing Management, $6^{\text {th }}$ ed., Prentice Hall, Upper Saddle River, NJ.

Kotler, P. and Pfoertsch, W. (2006), B2B Brand Management, Springer, Berlin.

Kvale, S. and Brinkmann, S. (2009), Interviews: Learning the Craft of Qualitative Research, Sage, Los Angeles.

Leek, S.and Christodoulides, G. (2011), "A literature review and future agenda for B2B branding: challenge of branding in a B2B context", Industrial Marketing Management, Vol.40 No.6, pp.830-837.

Liedner, R. (1993), Fast Food, fast Talk: Service Work and Routinization of Everday Life, University of California Press, Los Angeles. 
Li, F., Pienkowski, D., Van Moorsel, A. and Smith, C. (2012), "A holistic framework for trust in online transactions", International Journal of Management Reviews, Vol.14 No.1, pp. 85-103.

Lin, C.O.Y. and Yazdanifard (2014), "How Google's new algorithm, Hummingbird, promotes content and inbound marketing", American Journal of Industrial and Business Marketing, Vol.4, pp.51-57.

Lusch, R.F. and Vargo, S.L. (2009), "Service-Dominant Logic - a guiding framework for inbound marketing", Marketing Review St Gallen, Vol. 26 No.1, pp.6-10.

McCarthy, J. Rowley, J. and Ashworth, C. (2013), "Managing brand presence through social media: the case of UK football clubs", Internet Research, Vol. 24 No.2 Online.

McMaster, M. (2010), "B2B buyer behaviour on the digital frontier". Journal of Integrated Marketing Communications, pp.51-61.

Michaelidou, N., Siamagka, N.T. and Christodoulides, G. (2011), "Usage, barriers and measurement of social media marketing: an exploratory investigation of small and medium B2B brands", Industrial Marketing Management, Vol.40, No.7, pp.1153-1159.

Odden, L. (2012), Optimize. Wiley,Hoboken, N.J.

Muniz, A.M., and O'Guinn, T. (2001), "Brand community", Journal of Consumer Research, Vol. 27, No.4, pp.412-432.

Oestreicher-Singer, G. and Zalmanson, L. (2013), "Content or community? a digital business for content providers in the social age", MIS Quarterly, Vol.37, No.2, pp.591-616.

Peppers, D. and Rogers, M. (2011), Managing Customer Relationships: A Strategic Framework. 2nd ed., Wiley: Hoboken, N.J.

Pulizzi, J. (2012a), "The rise of storytelling as the new marketing", Publishing Research Quarterly, Vol.28, pp.116-123.

Pulizzi, J. and Barrett, N. (2008), Get Content, Get Customers, Voyager Media, Bonita Springs, Florida.

Quniton, S. (2013), "The community paradigm: a response to brand management's dilmma in the digital era." Journal of Marketing Management, Vol.29, Nos. 7-8, pp. 912-932.

Rieh, S. Y. (2002), "Judgement of information quality and cognitive authority in the web", Journal of the American Society for Information Science, Vol.53 No.2, pp.145-161.

Rockley, A. and Cooper, C. (2012), Managing Enterprise Content, New Riders, Berkeley, CA.

Rose, R. and Pulizzi, J. (2011), Managing Content Marketing, CMI Books, Cleveland, OH.

Rowley, J. (2002), "Reflections on customer knowledge management in e-business", Qualitative Marketing Research: An International Journal, Vol.5, No.4, pp.268-280.

Rowley, J. (2008), "Understanding digital content marketing", Journal of Marketing Management, Vol.24, Nos. 5-6, pp.517-540.

Saunders, M., Lewis, P. and Thornhill, A. (2009), Research Methods for Business Students, 5th ed., Pearson Education, Harlow.

Schwaiger, M. and Sarsted, M. (2011), "Corporate branding in a turbulent environment", Journal of Brand Management, Vol. 19, No.3, pp,179-181.

Scott, D.M. (2011), The New Rules of Marketing \& PR, Wiley, Hoboken, N.J.

Signorelli, J. (2012), Story Branding, Greenleaf Book Group, Austin, TX:

Silverman, D. (2010), Doing Qualitative Research: A Practical Handbook. Sage,London. 
Silverman, M. (2012), Capturing Community: How to Build, Manage and Market your Online Community. Content Marketing Institute, Cleveland, $\mathrm{OH}$.

Smith, P.R. and Chaffey, D. (2013), eMarketing eXcellence, $2^{\text {nd }}$ ed., Butterworth Heinemann, Oxford.

Stelzner, M. (2011), Launch, Wiley.Hoboken, N.J.

Tellefsen, T. (2002), "Commitment in business-to-business relationships: the role of organizational and personal needs", Industrial Marketing Management, Vol.31 No.8, pp.645-652.

Tillotson, J. (2002), "Web site evaluation: a survey of undergraduates", Online Information Review, Vol.26 No.6, pp.392-403.

Vargo. S.L. and Lusch, R.F. (2011), "It's all B2B... and beyond: toward a system perspective of the market", Industrial Marketing Management, Vol.40 No.2, pp.181-187.

Veloutsou, C. and Taylor, C.S. (2012), "The role of the brand as a person in business to business brands", Industrial Marketing Management, Vol.41 No.6, pp.895-1046.

Wallace, E. and De Chernatony, L. (2007), "Exploring managers' views about brand saboteurs", Journal of Marketing Management, Vol.23 No.1/2, pp.91-106

Wolk, A. and Theyson, S. (2007), "Factors influencing website traffic in the paid content market. Journal of Marketing Management, Vol.23, Nos. 7-8, pp.769-796.

Wuebben, J. (2012), Content is Currency, Nicholas Brealey, Boston, MA. 